\title{
Pengaruh PDRB indeks pemangunan manusia dan zakat terhadap kemiskinan di Provinsi Jawa Tengah
}

\author{
Muhammad Miftahussalam ${ }^{1}$, Mohammad Rofiuddin ${ }^{1^{*}}$ \\ 1Fakultas Ekonomi dan Bisnis Islam IAIN Salatiga,Indonesia \\ *Ko respodensi (mohammad.rofiudin@iain salatiga.ac.id)
}

\begin{abstract}
This study aimed to determine the effect of GRDP, human development ind ex, and zakat on poverty in Central Java Province. The object of th is research is all regencies/cities in Central Java Province in 2015-2019. The method used to see effects using the panel data regression approach is the fixed effect model. The results in the study show that simultaneously zakat, GRDP, human development index affect poverty in Central Java Province. GRDP is not significant to poverty in Central Java Province. While the human development index and zakat decrease poverty in Central Java Province. The research model clarifies the role of zakat and human development in poverty alleviation in Central Java Province, so it is essential to maintain and increase its value over time to reduce poverty.
\end{abstract}

Keywords: GRDP, Human development ind ex, Zakat, Poverty

\begin{abstract}
Abstrak
Penelitian ini bertujuan untuk mengetahui pengaruh PDRB, Indeks Pembangunan Manusia, dan Zakat terhadap Kemiskinan di Jawa Tengah. Objek penelitian ini adalah seluruh kabupaten/kota di Jawa Tengah tahun 2015-2019. Metode yang digunakan untuk melihat efek menggunakan pendekatan regresi data panel adalah Fixed Effect Model. Hasil penelitian menunjukkan bahwa secara simultan Zakat, PDRB, Indeks Pembangunan Manusia berpengaruh terhadap kemiskinan di Jawa Tengah. PDRB tidak signifikan terhad ap Kemiskinan di Jawa Tengah. Sedangkan Indeks Pembangunan Manusia dan Zakat menurunkan Kemiskinan di Jawa Tengah. Model penelitian memperjelas peran zakat dan pembangunan manusia dalam pengentasan kemiskinan di Provinsi Jawa Tengah, sehingga penting untuk mempertahankan dan meningkatkan nilainya dari waktu ke waktu untuk mengurangikemiskinan.
\end{abstract}

Kata Kunci : PDRB, In deks Pembangunan, Zakat, dan Kemiskinan

How to cite: Miftahussalam, M., \& Rofiuddin, M. (2021). Pengaruh PDRB, indeks
pembagunan manusia dan zakat terhadap kemiskinan di Provinsi Jawa
Tengah. Journal of Economics Research and Policy Studies, 1(1), 40-54.

\section{Pendahuluan}

Pada dasarnya tujuan didirikanya sebuah negara adalah memberikan kesejahteraan masyarakat. Namun dalam menciptakan kesejahteraan, pemerintah akan dibanyangi oleh permasalahan permasalahan seperti kemiskinan. Kemiskinan merupakan masalah yang belum bahkan susah dihilangkan di dunia ini. Perbedaan kemampuan, kesempatan, dan perbedaan sumber daya setiap manusia atau individu merupakan akibat dari kemiskinan. Kemiskinan meupakan masalah yang sudah mendunia yang artinya menjadi perhatian dunia dan masalah tersebut terjadi diseluruh negara lebih khususnya negara berkembang. 
Dalam penggangulangan kemiskinan pemerintahan baik pusat maupun daerah melakukan berbagai kebijakan dan program-program berupaya mengurangi kemiskinan namun masih jauh dari induk pemasalahan. Kebijakan dan program yang dilaksanakan pemerintah belum bisa menematkan hasil yang signifikan. Berkaitan dengan kemiskinan, Bappenas mendefiniikan bahwa kemiskinan adalah suatu situsi atau kondisi yang dialami seseorang atau kelompok orang yang tidak mampu menyelenggarakan hidupnya sampai suatu taraf yang dianggap manusiawi. Kemiskinan meliputi dimensi politik, sosial budaya dan psikologi, ekonomi dan akses terhadp aseet. Demensi tersebut seling terkait dan saling mengunci atau membatasi (Akbar, 2019).

Kemiskinan merupakan salah satu masalah yang selalu dihadapi oleh manusia. Masalah kemiskinan itu sama tuanya dengan usia kemanusiaan itu sendiri dan implikasi permasalahannya dapat melibatkan keseluruhan aspek kehidupan manusia, walaupun seringkali tidak disadari kehadirannya sebagai masalah untuk oleh manusia yang bersangkutan (Azizah, Sudarti, \& Kusuma, 2018). Terdapat beberapa faktor yang dapat mempengaruhi tingkat kemiskinan diantaranya adalah lapangan pekerjaan, kesehatan, inflasi, pajak, jumlah penduduk dan lain sebagainya. Kemiskinan menurut (BPS, 2020) adalah ketidakmampuan memenuhi dasar makanan dari sisi ekonomi dan bukan makanan yang diukur dari sisi pengeluaran, jadi penduduk miskin merupakan penduduk yang memiliki rata-rata pengeluaran perkapita perbulan dibawah garis kemiskinan. Negara dikatakan maju apabila memiliki angka kemiskinan yang rendah.

Negara indonesia tingkat kemiskinan secara umum mengalami tren menurun dari tahun ke tahun khususnya di jawa tengah menurut Badan Pusat Statistik (BPS) menujukan Bahwa presentasi tingkat kemiskinan mengalami penurunan dari tahun 2015 - 2019 yaitu sesuai Gambar 1.

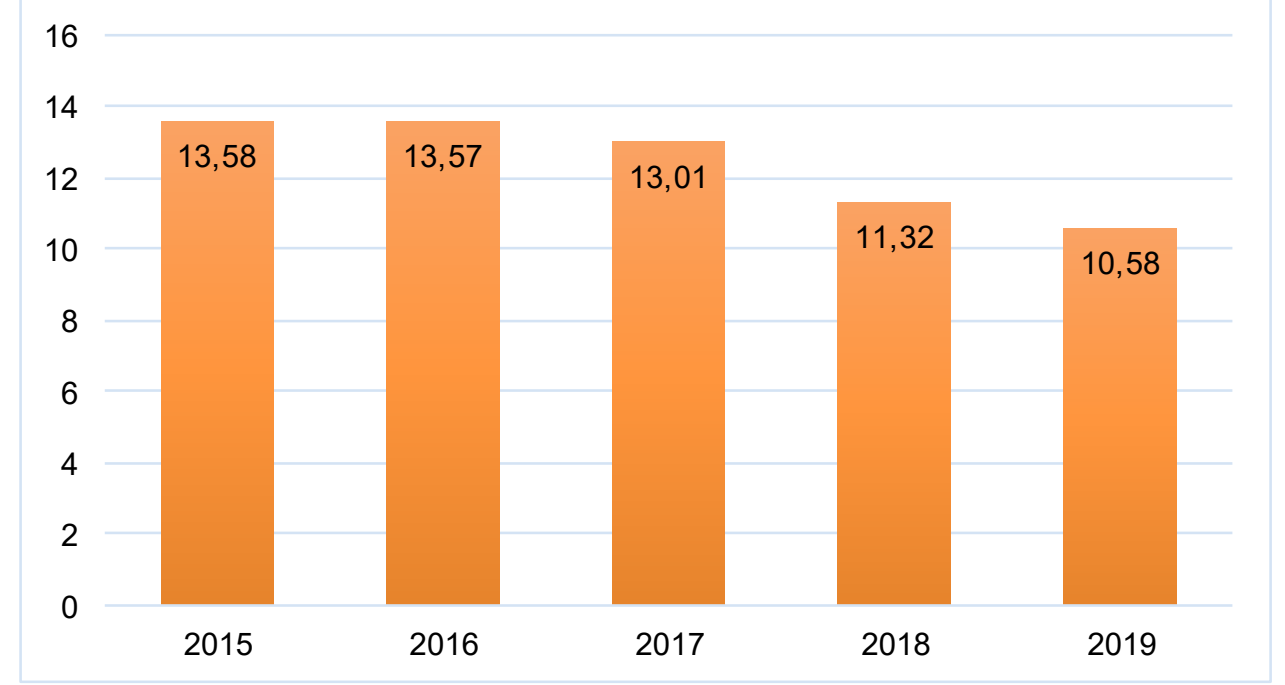

Gambar 1. Presentasi penduduk miskin Provinsi jawa tengah

Sumber: Badan Pusat Statistik Jawa Tengah (BPS)

Dari Gambar 1 kemiskinan di jawa tengah bahwa tahun ke tahun presentasi penduduk miskin megalami tren penurunan, terbukti pada tahun 2015 pendunduk 
miskin 13,58\% sampai tahun 2019 10,80\%. Dengan adanya faktor tersebut, pemerintah berupaya mengatasi kemiskinan dengan berkerja keras secara maksimal dan menerapkan kebijakan - kebijakan tentang mengganggulangi kemiskinan, maka tingkat kemiskinan yang ada di indonesia khususnya jawa tengah dapat berkurang dan kesejahteraan rakyat indonesia dapat bertambah.

Angka kemiskinan juga dapat ditekan dengan zakat. zakat merupakan alat bantu sosial mandiri yang menjadi kewajiaban moral bagi orang kaya untuk membantu mereka yang miskin dan terabaikan sehingga kemelaratan dan kemiskinan terhapuskan dari masyarakat. Zakat dapat meningkatkan pendapatan orang orang miskin. Karena redahnya pendapatan mereka, tambahan pendapatan tersebut akan digunakan keseluruhannya untuk membeli barang-barang dan jasa-jasa pokok (Azizah et al., 2018)

Hubungan kemiskinan dengan zakat dalam islam saling terpengaruh, karena salah satu alternatif dalam islam untuk mengatasi ketimpangan dan kemiskinan adalah dengan menghimpun dana zakat dan menyalurkan zakat tersebut tepat sasaran. Dengan adanya zakat, para fakir miskin dapat turut perpatisipasi dalam kehidupan bemasyarakatan dan dapat meningkatkan pendapatan masyarakat fakir miskin dan mengurangi kemiskinan sehingga terciptanya pembangunan yang merata. Dalam penelitihan sebelumnya (Rini, Fatimah, \& Purwanti, 2020) menjelaskan bahwa zakat memiliki pengaruh positif terhadap kemiskinan. Sementara (Tawakkal \& Sapha, 2018) menjelaskan bahwa zakatBerpengaruh Negatif terhadap kemiskinan.

Penurunan tingkat kemiskinan juga dapat dilihat dari Produk Domestik Regional Bruto (PDRB) disuatu daerah bukan hanya kebijakan kebijakan pemerintah saja. PDRB menurut Badan Pusat Statistik adalah jumlah dari nilai tambah yang dihasilkan oleh seluruh sektor usaha dalam suatu wilayah tertentu, atau merupakan jumlah nilai barang dan jasa akhir yang dihasilkan oleh seluruh unit kegiatan ekonomi. PDRB merupakan salah satu indikator penting dalam suatu daerah yang digunakan sebagai perencanaan dan mengatur sampai sejauh mana keberhasilan pemerintah dalam memamfaatkan sumber daya yang ada dan pengambilan keputusan yang salah satunya untuk mengurangi jumlah kemiskinan. Berkitan dengan PDRB penelitian sebelumnya yang dilakukan oleh Saputra (2011b) bahwa PDRB berpengaruh Negatif terhadap Kemiskinan dan Berbeda dengan penelitian yang dilakukan oleh Bintang dan Woyanti (2018) yang mengasilkan PDRB memiliki hubungan positif terhadap kemiskinan.

Hubungan Produk Domestik Regional Bruto (PDRB) terhadap kemiskinan antara lain yaitu pertumbuhan ekonomi yang tinggi dan berkelanjutan merupakan kondisi utama atau suatu keharusan bagi kelangsungan pembangunan ekonomi dan peningkatan kesejahteraan. Pertumbuhan ekonomi tanpa diiringi dengan penambahan kesempatan kerja akan mengakibatkan ketimpangan dalam pembagian dari penambahan pendapatan, yang selanjutnya akan menciptakan suatu kondisi pertumbuhan ekonomi dengan peningkatan kem iskinan (Asriyanti, 2020). 
Salah satu faktor yang mempengaruhi kemiskinan adalah inflasi. Inflasi merupakan suatu kondisi yang bercenderungan dari harga yang naik secara umum dan terus menerus. Kenaikan satu atau dua barang saja tidak disebut inflasi, kecuali kenaikan tersebutmeluas dan mengakibatkan pada sebagian besar dari harga-harga barang lain. Jika inflasi mengalami fluktuasi, maka kegiatan perekonomian akan cenderung menyesuaikan dengan kondisi yang terjadi. Dampak dari kenaikan inflasi menyebabkan menurunnya daya beli masyarakat. Dikarenakan nilai riil pada mata uang mengalami penurunan (Lubis, 2017).

Selain faktor fakor diatas, indikator lain yang dapatmem pengarui naik dan turunya kemiskinan adalah Indeks Pembangunan Manusia (IPM). IPM merupakan indeks komposit yang dihitung sebagai rata-rata sederhana dari 3 indeks yang menggambarkan kemampuan dasar manusia dalam memperluas pilihan-pilihan, yaitu Indeks Harapan Hidup, Indeks Pendidikan, dan Indeks standart hidup layak (Rossalia, 2019). Penelitian ini di didukung oleh penelitian yang dilakukan oleh Sayifullah dan Gandasari (2016) bahwah IPM berpengaruh negatif terhadap kemiskinan, berbeda dengan penelitian yang dilakukan oleh Alhudhori (2017) bahwa IPM berpengaruh positif terhadap kemiskinan.

Hubungan antara IPM dan Kemiskinan berkorelasi negatif di suatu wilayah di karenakan jika nilai IPM tinggi maka seharusnya tingkat kemiskinan disuatu wilayah rendah. Indeks pembangunan manusia dapat dilihat dari kualitas sumber daya manusia, rendahnya Indeks pembangunan Manusia (IPM) mengakibatkan rendahnya produktivitas kerja dari penduduk sehingga timbulnya pendapatan yang rendah yang menjadikan jumlah penduduk miskin tinggi.

\section{Tinjauan Pustaka}

\section{Kemiskinan}

Regnar nurkse adalah yang pertama kali mengenalkan teori lingkaran setan kemiskinan. Lingkaran kemiskinan diartikan sebagai suatu rangkaian kekuatan yang saling mempengaruhi satu sama lain sehingga dapat menimbulkan suatu kondisi dimana suatu negara akan tetap miskin dan akan mengalami kesulitan untuk mencapai tingkat pembangunan yang lebih tinggi. Menurut nurkse, kemiskinan juga dapat menghabat pembangunan dimasa yang akan datang. Menurut nurks salah satu faktor yang menyebabkan adanya lingkaran kemiskinan yaitu adanya hambatan dalam proses pembentukan modal yang sangat kuat (Indahsari, 2019).

Terdapat dua jenis lingkaran kemiskinan menurut pandangan nurkse yang menjadi penyebab tidak tercapainya tingkat pembangunan yang pesat yaitu, dari segi permintaan modal dan penawaran modal. Dari segi permintaan modal, investasi yang rendah merupakan faktor pendorong yang disebabkan oleh terbatasnya luas pasar untuk berbagai jenis barang. Tingkat pendapatan masyarakat yang rendah merupakan penyebab terbatasnya pasar yang diakibatkan karena produktivitas juga rendah. Produktivitas yang rendah ini disebabkan karena terbatasnya pembentukan modal di masa lampau akibat dari kekurangan faktor pendorong kegiatan investasi. 
Sedangkan dari segi penawaran modal. Rendahnya tingkat produktivitas akan mengakibatkan tingkat pendapatan masyarakat juga rendah, pendapatan masyarakat rendah akan berdampak pada kemampuan masyarakat yang rendah untuk menabung, akibat dari rendahnya masyarakat untuk menabung maka tingkat pembentukan modal juga rendah. Hal ini akan berdampak pada suatu negara akan berhadapan dengan kekurangan barang barang modal, dengan demikian tingkat produktivitas akan tetap berada tingkat yang rendah.

Teori lingkaran setan menurut Nurkse menunjukkan bahwa keterbelakangan merupakan suatu hal yang harus diputus dari sesuatu rantai lingkaran setan untuk mengatasi masalah kemiskinan yang terjadi, hal ini dapat diatasi dengan meningkatkan mutu sumber daya manusia, yaitu dengan pendidikan yang berkualitas yang diselenggarakan untuk penduduknya di setiap negara dengan tujuan memiliki ilmu pengetahuaan yang baik sehingga keterbelakangan tidak terjadi, dengan demikian dapat membuktikan bahwa mutu pendidikan dan peningkatan indeks pembangunan manusia sangat penting untuk pengetasan kemiskinan (Rossalia, 2019).

Kemiskinan adalah sebagai kondisi deprivasi materi dan sosial yang menyebabkan individu hidup di bawah standar kehidupan yang kayak atau kondisi dimana individu mengalami deprivasi relatif dibandingkan individu yang lainya dalam masyarakat. Pendekatan yang digunakan pengertian tentang kemiskinan ada dua yaitu; pertama, pendekatan absolut yang menekankan pada pemenuhan kebutuhan fisik minimun yang harus dipenuhi seseorang atau keluarga agar dapat melangsungkan hidupnya pada teraf lebih layak. Yang kedua adalah pendekatam relatif dimana kemiskinan ditentukan berdasarkan teraf hidup relatif dalam masyarakat (BPS, 2020).

Indikator kemiskinan adalah sebagai berikut: 1) Headcount Index yaitu indeks yang mengukur presentase penduduk yang berada di bawah garis kemiskinan terhadap total penduduk.Semakin kecil angka indeks, maka semakin menurun angka kemiskinan, atau sebaliknya. Headcount Index berbanding lurus dengan jumlah kemiskinan. 2) Poverty Gap Index ( Indeks Kedalaman Kemiskinan) merupakan ukuran rata-rata kesenjangan pengeluaran masing-masing penduduk miskin terhadap garis kemiskinan.semakin kecil nilai indeks, berarti menujukkan secara rata-rata penduduk miskin sudah mendekati garis kemiskinan dan semakin tinggi nilai indeks, maka semakin jauh dari garis kemiskinan. 3) Poverty Severity Indeks (Indeks Keparahan Kemiskinan) yaitu untuk memberikan gambaran penyebaran penduduk miskin.semakin tinggi nilai indeks, maka semakin tinggi ketimpangan pengeluaran penduduk miskin (Rossalia, 2019)

\section{Produk Domestik Regional Bruto}

Menurut BPS bahwa Produk Domestik Regional Bruto (PDRB) adalah jumlah nilai tambah yang dihasilkan oleh seluruh unit usaha dalam suatu wilayah, atau merupakan jumlah seluruh nilai barang dan jasa akhir yang dihasilkan oleh seluruh unit ekonomi di suatu wilayah. PDRB dapat menggambarkan kemampuan suatu 
daerah dalam mengelola sumber daya yang dimilikinya. Oleh karena itu, besaran PDRB yang dihasilkan oleh masing-masing daerah sangat bergantung kepada potensi faktor-faktor produksi di daerah tersebut (Aminah, 2018).

Produk Domestik Regional Bruto menurut merupakan nilai dari seluruh produksi barang dan jasa yang dihasilkan masyarakat tertentu (dalam kurun waktu tertentu)/1 tahun. PDRB merupakan indikator untuk mengatur sampai sejauh mana keberhasilan pemerintah dalam memanfaatkan sumber daya yang ada dan dapat digunakan sebagai perencanaan dan pengambilan keputusan yang salah satunya untuk mengurangi jumlah kemiskinan (Mustika, 2019).

Menghitung PDRB dapat diperoleh melaluoi tiga pendekatan yaitu pendekatan prouksi, pendekatan pendapatan dan pendekatan pengeluaran yang dijelaskan sebagai berikut:

a) Menurut pendekatan produksi, PDRB adalah jumlah nilai barang dan jasa akhir yang dihasilkan oleh berbagai unit produksi di suatu wilayah dalam jangka waktu tertentu (satu tahun). Unit-unit produksi tersebut dalam penyajiannya dikelompokkan menjadi 9 sektor atau lapangan usaha yaitu; Pertanian, Pertambangan dan Penggalian, Industri Pengolahan, Listrik, Gas dan Air Bersih, Bangunan, Perdagangan, Hotel dan Restoran, Pengangkutan dan Komunikasi, Jasa Keuangan, Persewaan dan Jasa Perusahaan, Jasa-jasa.

b) Menurut pendekatan pengeluaran, PDRB adalah penjumlahan semua komponen permintaan akhir yaitu: Pengeluaran konsumsi rumah tangga dan lembaga swasta yang tidak mencari untung; Konsumsi pemerintah; Pembentukan modal tetap domestik bruto; Perubahan stok. ; Ekspor netto.

c) Menurut pendekatan pendapatan, PDRB merupakan jumlah balas jasa yang diterima oleh faktor produksi yang ikut serta dalam proses produksi dalam suatu wilayah dalam jangka waktu tertentu (satu tahun). Balas jasa faktor produksi yang dimaksud adalah upah dan gaji, sewa rumah, bunga modal dan keuntungan. Semua hitungan tersebut sebelum dipotong pajak penghasilan dan pajak lainnya (Saputra, 2011b).

Kesimpulan dari ketiga pendekatan di atas akan mengahasilkan angka yang sama. Yang artinya jika jumlah pengeluaran menjadi sama dengan jumlah barang dan jasa akhir yang dihasiokan dan diharuskan dma dengan jumlah pendapatan untuk faktor faktor produksi. Cara ini disebut sebagai PDRB atas dasar harga pasar karena pajak tak lansung neto termasuk di dalamnya

Penyajian Produk Domestik Regional Bruto disusun dalam dua bentuk, yaitu :

a) Produk Domestik Regional Bruto Atas Dasar Harga Konstan, yaitu jumlah nilai produksi atau pengeluaran atau pendapatan yang dihitung menurut harga tetap. Dengan cara mendefinisikan berdasarkan harga-harga pada tingkat dasar dengan menggunakan indeks harga konsumen. Dari perhitungan ini tercemin tingkat kegiatan ekonomi yang sebenarnya melalui Produk Domestik Regional Bruto riilnya. 
b) Produk Domestik Regional Bruto Atas Dasar Harga Berlaku, menurut BPS adalah jumlah nilai tambah bruto yang timbul dari seluruh sektor perekonomian di suatu wilayah. Nilai tambah yang dimaksud merupakan nilai yang ditambahkan kepada barang dan jasa yang dipakai oleh unit produksi dalam proses produksi sebagai input antara. Nilai yang ditambahkan ini sama dengan balas jasa atas ikut sertanya faktor produksi dalam proses produksi (Aminah, 2018).

\section{Indeks Pembangunan Manusia}

Menurut Badan Pusat Statistik, Indeks Pembangunan Manusia (IPM) merupakan ukuran capaian pembangunan manusia berbasis sejumlah komponen dasar kualitas hidup. IPM menggambarkan beberapa komponen, yaitu capaian umur panjang dan sehat yang mewakili bidang kesehatan, angka melek huruf, partisipasi sekolah dan rata-rata lamanya bersekolah mengukur kinerja pembangunan bidang pendidikan, dan kemampuan daya beli masyarakat terhadap sejumlah kebutuhan pokok yang dilihat dari rata- rata besarnya pengeluaran per kapita. IPM atau dikenal dengan sebutan Human Development Index (HDI) adalah indikator yang digunakan untuk mengukur salah satu aspek penting yang berkaitan dengan kualitas dari hasil pembangunan ekonomi, yakni perkembangan manusia (Sayifullah \& Gandasari, 2016).

Indeks Pengembangan Manusia terdiri dari 3 (tiga) komponen yang mempengaruhi tingkatkeberhasilan pembangunan manusia yakni:

a) Komponen Kesehatan, dalam indeks pembangunan manusia, komponen kesehatan ini tercermin dalam usia harapan hidup masyarakat yaitu rata-rata perkiraan banyak tahun yang dapat ditempuh seseorang selama hidup. Ada dua jenis data yang digunakan dalam penghitungan Angka Harapan Hidup yaitu Anak Lahir Hidup (ALH) dan Anak Masih Hidup (AMH). Sementara itu untuk menghitung indeks harapan hidup digunakan nilai maksimum harapan hidup sesuai standar UNDP, dimana angka tertinggi sebagai batas atas untuk penghitungan indeks dipakai 85 tahun dan terendah 25 tahun.

b) Komponen Pendidikan, dalam indeks pembangunan manusia komponen pendidikan diwakili oleh Angka Melek Huruf $(\mathrm{AMH})$ dan Rata-rata Lama Sekolah. Angka Melek Huruf adalah perbandingan antara jumlah penduduk usia 15 tahun ke atas yang dapat membaca dan menulis dengan jumlah penduduk usia 15 tahun ke atas. Batas maksimum untuk angka melek huruf adalah 100 sedangkan batas minimum adalah 0 (standar UNDP). Hal ini menggambarkan kondisi 100 persen atau semua masyarakat mampu membaca dan menulis, dan nilai nol menceminkan kondisi sebaliknya. Sedangkan Rata-rata lama sekolah adalah rata-rata jumlah tahun yang dihabiskan oleh penduduk yang berusia 15 tahun ke atas untuk menem puh semua jenis pendidikan formal yang pemah dijalani. Batas maksimum untuk rata-rata lama sekolah adalah 15 tahun dan batas minimum sebesar 0 tahun (standar UNDP).

c) Komponen Daya Beli, dalam indeks pembangunan manusia komponen daya beli diwakili oleh Pendapatan Perkapita Riil yang Disesuaikan yaitu rata-rata 
pengeluaran perkapita penduduk yang sudah distandarkan dengan mendeflasikan melalui indeks harga konsumen (Alhudhori, 2017).

\section{Zakat}

Zakat menurut bahasa dari bahas arab yang merupakan bentuk masdhar dari kaya Zaka yang berati berish (al Thuhr), tubuh (az-zayiddah), berkah dan pujian (al-Madh) Menurut madzhabhambali, zakat ialah kewajiban yang harus dilaksanakan terhadap harta tertetu untuk kelompok tertentu pada waktu tertentu pula. Kemudian menurut ulama madzab maliki zakat merupakan mengeluaran bagian tertentu dari harta tertentu yang telah mencapai nisab untuk orang-orangang berhak menerimanya ketika telah sempurna kepemilikanya, telah berulang tahun selain tambang dan alat pertanian. Sehingga dapat disimpulkan bahwah definisi zakat ialah bagian tertentu dari harta tertentu yan di keluarkan atau disalurkan dega cara dan syarat tertent kepada rang atau lem baga tertentu pula (Sulistiano, 2020).

Dalam ajaran syariat islam golongan yang berhak mendapatkan zakat tergolong 8 asnaf, yaitu fakir, miskin, amil, mualaf, riqob, gharim, fi sabilillah (orang yang berjuang di jalan Allah), dan ibn sabil. 8 asnaf telah dijelaskan didalam Al Quran Surah At-Taubah Ayat 60 yang artinya "Sesungguhnya shadaqoh (zakat) itu hanyalah untuk orang-orang fakir, orang-orang miskin, pengurus-pengurus zakat, para muallaf yang dibujuk hatinya, untuk (memerdekakan) budak, orang-orang yang berhutang, untuk jalan Allah, dan orang-orang yang sedang dalam pejalanan, sebagai suatu ketetapan yang diwajibkan Allah dan Allah Maha Mengetahui lagi Maha Bijaksana".

Fordebi (Forum Dosen Ekonomi Islam) (2016) dalam ajaran islam dan perdagangan masyarakat islam mempunyai golongan penduduk yang berlebihan dan keterbatasan. Berkewajiban untuk mengeluarkan hartanya bagi orang yang kelebihan hartanya. Terdapat beberpa indikator bagi pemberi zakat (muzakki) sebagai berikut: 1) Beragama islam. 2) Merdeka, Orang yang merdeka diwajibkan membanyar zakat kecuali hamba sahaya yang tidakdi wajibkan membanyar zakat. 3) Dimiliki secara sempurna, Harta benda yang wajib dibayarkan zakatnya adalah harta benda yang dimiliki secara sempurna oleh orang muslim yang artinya harta benda tersebut bukan harta dari hutang atau harta orang lain. 4) Mencapai nisab, Wajib membanyar zakat jika seorang muslim jika harta yang dimilikinya mencapi nishab. Nishab zakat berbeda - beda tergantung jenis harta bendanya.

\section{Metode Penelitian}

Penelitian ini alat yang dipakai yaitu analisis regresi data panel, data panel merupakan gabungan Time Series dan Cross Section dimana lokasi dalam penelitian ini yaitu 35 Kabupanten dan Kota di Jawa Tengah. Data yang digunakan dalam penelitaian ini adalah sata sekunder yang ambil dari laporan Badan Pusat Statistik (BPS) dan BAZNAS khususnya tahun 2015 - 2019. Data yang diteliti meliputi Kemiskinan, Zakat, PDRB dan Indeks Pembangunan Manusia (IPM). 
Metode yang dipakai dalam penelitian ini merupakan metode analisis data panel. Metode analisis data panel merupakan gambungan antara deret waktu (time series) dengan analisis deret wilayah (cross Section) (Iskandar et al., 2019; Mohammad \& Firmansyah, 2018; Rofiuddin et al., 2019) Terdapa bentuk regresi untuk data panel di dalam penelitian ini adalah sebagai berikut:

$$
T K=\beta 0+\beta 1 I P M+\beta 2 P D R B+\beta 3 \text { Zakat }+\mu i t
$$

TK merupakan kemiskinan, PDRB merupakan Produk domestik regional bruto, IPM singkatan Indeks Pembangunan Manusia, Zakat

Ada Beberapa keuntungan yang akan kita dapatkan didalam menggunakan data panel. Menurut Widarjono (2013) keuntungan - keuntungan yang diperoleh diantaranya adalah data panel merupakan gabungan dua data time series dan cross section mampu untuk menyediakan data lebih banyak sehingga akan menghasilkan degree of freedom yang lebih besar. selanjutnya didalam menyatukan informasi dari data rentang waktu time series) dan rentang wilayah (cross section) mampu untuk mengatasi masalah yang muncul saat ada masalah penghilangan variabel.

\section{Model Regresi Data Panel}

Estimasi model regresi data panel dapat dilakukan dengan tiga pendekatan yaitu dengan pendekatan commond effect model, fixid effect model dan menggunakan rendom effect model. Pendekatan common effect model merupakan pendektan paling serdemana, hanya dengan menggambungkan data time series dan cross section tampa memerhatikan dimensi individu dan waktu maka mengunakan metode OLS (Orginary Least Square) dalam mengatimasi model data panel. Dalam pendekatan ini, common effect model tidak memperhatikan dimensi antara individu maupun waktu sehingga diasumsikan bahwa perilaku data antara kabupaten sama dalam berbagai kurun waktu. Model Common Effect Model dapat dituliskan sebagai berikut:

$$
\text { Yit }=\beta o+\beta 1 P D R B i t+\beta 2 I P M t+\beta 3 \text { Zakatit }+ \text { eit }
$$

Pada model fixed effect, konstanta untuk masing-masing individu akan berbeda (jika dalam hal ini adalah perusahaan) walaupun koefisien (slope) pada masingmasing variabel independen akan tetap. Maka dari itu untuk membedakan objek yang satu dengan yang lain, digunakan variabel dumi. Maka model ini sering disebut dengan LSDV (Least Square Dummy Variabels). Model fixid effect dengan mengunakan tekinik dummy dapat dituliskan sebagai berikut:

$$
\text { Yit }=\beta o+\beta 1 P D R B i t+\beta 2 I P M t+\beta 3 \text { Zakatit }+ \text { eit }
$$

Pendekatan fixed effect menggunakan LSDV dapat menghalangi kita untuk mengetahui model aslinya. Sehingga estimasi parameter model regresi data panel perlu menggunakan model komponen error atau disebut juga sebagai model efek acak (random effect). Regresi ini digunakan untuk mengatasi kelemahan metode efek tetap yang menggunakan variabel semu. Metode random menggunakan 
residual yang diduga memiliki hubungan antar waktu dan antar objek. Pendekatan ini dapat ditulis sebagai berikut:

$$
\text { Yit }=\beta o+\beta 1 P D R B i t+\beta 2 I P M t+\beta 3 \text { Zakatit }+ \text { eit }
$$

Untuk pemilihan model yang akan digunkankan dalam sebuah penelitihan perlu dilakukan berdasarkan pertimbangan statistik. Hal ini dilakukan untuk memilih model yang tepat maka perlu adanya beberapa metode pengujian yang dapat dilakukan, yaitu:

a) Uji Chow, Uji ini digunakan untuk memilih salah satu model pada regresi data panel, dengan menambahkan variabel dummy sehingga dapat diketahui bahwa intersepnya berbeda dan dapat di uji dengan chow-test dengan likelihood ratio. Uji chow merupakan pengujian yang digunakan untuk menentukan model yang digunakan akan menggunakan model common effect atau model fixed effect.

b) Uji Hausmen, Uji ini digunakan untuk memilih model random effect dengan model fixed effect. Uji ini bekerja dengan menguji apakah terdapat hubungan antara galat pada model (galat komposit) dengan satu atau lebih variabel independen dalam model

c) Uji LM Test, Uji LM test digunakan untuk membandingkan atau memilih model yang terbaik antara modal efek tetp maupun koefisien tetap. Peguji ini didasarkan pada distribusi chi asuare dengan derajat kebebasan (df) sebesar jumalh variabel independen. Pengambilan keputusan merupakan jika nilai breusch pagan lebih besar dari 0.05, maka model yang dipilih adalah commoin efect, sebaliknya jika nilai breusch pagan lebih kecil dari 0.05 , maka model yang dipilih adalah radom effect.

\section{Hasil dan Pembahasan}

\subsection{Hasil Penelitian}

Tabel 1. Hasil Penelitian

\begin{tabular}{lccc}
\hline Variabel & CEM & FEM & REM \\
\hline Kemiskinan & $53,24675^{*}$ & $88,37709^{*}$ & $82,80084^{*}$ \\
PDRB & $0,599870^{* * *}$ & $-0,124434^{* * *}$ & $-0,069059^{* * *}$ \\
IPM & $-0,628839^{*}$ & $-1,055493^{*}$ & $-0,983783^{*}$ \\
Zakat & $2,22 \mathrm{E}-07^{* *}$ & $-6,83 \mathrm{E}-07^{* *}$ & $-4,97 \mathrm{E}-07^{*}$ \\
\hline R-squared $^{a}$ & 0,980944 & & \\
F-statistic $^{a}$ & 190,6060 & & \\
Prob(F-statistic) $^{a}$ & 0,000000 & & \\
\hline Note : ${ }^{*}$ Signifikan Pada 0,01, ${ }^{* *}$ Signifikan Pada 0,05, ${ }^{* * *}$ Signifikan Pada 0.10, &
\end{tabular}

Tabel 2. Pemilihan Model

\begin{tabular}{ccc}
\hline Penyesuaian Model & Prob & Model terpilih \\
\hline UJI Chow-test & 0,000 & FEM \\
Uji Hausmen & 0,000 & FEM \\
\hline
\end{tabular}

Berdasarkan pengujian Penyesuaian Model pada Tabel 2 penenelitain ini mengunakan Model Fixed Effect 


\section{Uji Koefisien Determinasi(R2)}

Koefisien deteminasi $\left(R^{2}\right)$ digunakan untuk menunjukan sejauh mana tingkat hubungan dan pengaruh variabel independen mempengeruhi variabel dependen. Besarnya nilai adjusted $R$ square antara $0<R^{2}<1$. Jika nilai $R^{2}$ semakin mendekati tinggi variasi variabel dependen yang dapat dijelaskan oleh variabel independennya.

Berdasarkan hasil analisis yang disajikan pada Tabel 1 diketahui bahwa nilai koefisuen determinasi untuk model regresi antara variabel independen dan dependen pada R-squared yaitu 0,980944 yang artinya bahwa variasi variabel independen dapat mempengauhi sebesar $98,09 \%$ pada probabilitas, sedangkan sisanya dipengaruhi oleh variabellain yang tidak dimasukan ke dalam model penelitian ini

\section{Uji F Statistik}

Uji F dipakai dalamm menguji apakah semua variabel independen dan variabel independen secara bersama-sama memiliki pengaruh ataupun tidak berpengaruh terhadap variabel dependen.

Berdasarkan hasil Model Fixed Effect Pada Tabel 1 diketahui $F$ hitung Statistik sebesar 190,6060 dan Probabilitas sebesar 0,000 pada tingkat signikikansi $\alpha=0,05$ maka koefisien $F$ statistik tersebut signifikan karena $P: 0,000<0,05$, maka Ho ditolak. sehingga dapat disimpulkan hasil pengujian ini, bahwa secara silmultan atau bersama-sama mengatakan PDRB, Indeks Pembangunan Manusia (IPM) dan Zakat Berpengaruh terhadap kemiskinan

\section{Uji Validitas pengaruh (Uji T)}

Uji T merupakan pengujian koefisien regresi secara individual dan untuk mengetahui dari masing-masing variabel dalam mempengaruhi variabel dependen, dengan menganggap variabel lain konstan atau tetap. Berikut Hasil dari Uji T di bawah ini:

a) Variabel PDRB, dari hasil pengujian ini diperoleh koefisien negatif PDRB sebesar 0,124434 dan nilai probabilitas 0,3165. Pada tingkat signifikansi $\alpha: 5 \%$ maka koefisien regresi tersebut tidak signifikan karena $P=0,3165>0,05$ maka dapat disimpulkan PDRB tidak Signifikan terhadap kemiskinan sehingga $\mathrm{H}_{1}$ penelitian ini ditolak.

b) Variabel IPM, dari hasil pengujian diperoleh koefisien Negatif sebesar 1,055493 dengan nilai probabilitas 0,0000 . Pada tingkat signifikansi $\alpha: 5 \%$ maka koefisien regresi tersebut signifikan karena $P=0,0000<0,05$ maka dapat disimpulkan IPM perpengaruh Negatif terhadap kemiskinan sehingga $\mathrm{H}_{2}$ penelitian ini tidak ditolak.

c) Variabel Zakat, dari hasil pegujian ini diperoleh koefisien negatif zakat sebesar 6,83E-07 dengan nilai probabilitas 0,0000. Pada tingkat signifikansi $\alpha: 5 \%$ maka koefisien regresi tersebut signifikan karena $P=0,0000<0,05$ maka dapat disimpulkan zakat perpengaruh negatif terhadap kemiskinan sehingga $\mathrm{H}_{3}$ penelitian ini tidak ditolak.

\subsection{Pembahasan}

\section{Produk domestik regional bruto dan Kemiskinan}


Variabel PDRB itu menunjukan hasil yang tidak signifikan,artinya naik turunya PDRB tidak Mempengaruhi Kemiskinan. Secara teoritis penelitian ini tidak sejalan dengan pendapatnya (Giovanni, 2018) bahwa indikator keberhasilan pembangunan yaitu pertumbuhan ekonomi dan syarat (Necessary Condition) bagi pengurangan tingkat kemiskinan. Syarat kecukupanya ialah bahwa pertumbuhan ekonomi efektif dalam mengurangi tingkat kemiskinan yang artinya pertumbuhan tersebut hendaknya menyebar disetiap golongan pendapatan, termasuk di golongan penduduk miskin. Penelitian ini sejalan dengan pendapatnya Wijayanto (2016) bahwa PDRB tidak berpegaruh terhadap kemiskinan akan tetapi tidak sejalan dengan pendapatnya Saputra (2011) bahwa PDRB berpengaruh negatif terhadap kem iskinan.

Pertumbuhan ekonomi ialah salah satu kunci penurunan kemiskinan di suatu wilayah karena pertumbuhan ekonomi akan menigkatkan kesejahteraan masyarakat, sehingga mengurangi tingkat kemiskinan. Pada hakekatnya pembangunan daerah diharuskan tidak hanya memuaskan perhatian pada pertumbuhan ekonomi saja akan tetapi mempertimbangkan bagaimana kemiskinan yang dihasilkan dari suatu proses pembangunan wilayah. Dengan meningkatkan laju perumbuhan ekonomi setinggitingginya akan menciptakan pendapatan per kapita sehingga secara otomatis kemakmuran masyarakat akan meningkatjuga (Saputra, 2011).

\section{Pengaruh Indeks Pertumbuhan Manusia dan Kemiskinan}

Indeks Pertumbuhan Manusia Berpengaruh Negatif Terhadap Kemiskinan di Jawa Tengah. Artinya setiap ada kenaikan IPM akan berdampak pada penurunan Kemiskinan. Secara teoritis penelitian ini sejalan dengan pendapatnya Alhudhori (2017) bahwa IPM salah satu tolak ukur pembangunan suatu wilayah yang berkorelasi negatif terhadap kondisi kemiskinan karena nilai IPM tinggi, idialnyaa kualitas hidup masyarakat juga tinggi sehingga tingkat kemiskinan rendah. Secara empiris penelitian ini sejalan dengan pendapatnya Rossalia (2019) bahwa IPM berpengaruh negatif terhadap kemiskinan, begitu juga pendapatnya (Lestari, 2017) bahwa IPM berpengaruh Negatif terhadap kemiskinan.

Indeks pembangunan manusia mempunyai pengaruh dalam penurunan kemiskinan karera memilikii faktor komposit dalam penghitungannya yaitu angka harapan hidup, angka melek huruf dan konsumsi perkapita. Peningatan sektor kesahatan, pendidikan dan pedapatan per kapita memberikan kotribusi bagi pembangunan manusia sehingga semakin tinggi kualitas manusia pada suatu wilayah akan mengurangi jumlah penduduk miskin di wilayah tersebut. Indeks pembangunan mempunyai tiga dimensi penting dalam pembangunan manusia ialah terkait dengan aspek pemenuhan kebutuhan akan hidup panjang umur dan hidup sehat agar mendapatkan pengetahuan dan mempunyai akses kepada sumber daya yang bisa memenuhi standar hidup, artinya, tiga dimensi penting dalam pembangunan manusia itu sangat berpengaruh terhadap kemiskinan (Sayifullah \& Gandasari, 2016).

\section{Pengaruh Zakat dan Kemiskinan}


Zakat berpengaruh Negatif terhadap kemiskinan di Jawa Tengah, artinya jika zakat bertambah maka dibarengin dengan penurunan kemiskinan. Secara teoritis penelitian ini sejalan dengan pendapanya Murniati dan Beik (2012) bahwa tujuan zakat adalah untuk mengetaskan beragram persoalan masyarakat kemiskinan dan penyebutan asnaf fakir dan miskin sebagai dua kelompok pertama zakat dalam al quran zakat bertujuan untuk mengurangi angka kemiskinan. Secara empiris penelitain ini sejalan dengan Akbar (2019) bahwa zakat berpengaruh negatif terhadap kemiskinan. Berbeda dengan pendapatnya Rini et al. (2020) bahwa zakat berpegaruh positif terhadap kemiskinan.

Zakat pada konteks kemiskinan merupakan salah satu tambahan pemasukan karena akan mendorong kenaikan pemintaan barang. Zakat juga digunakan sebagai alat pemberdayaan masyarakat sehingga mampu mendorong penduduk miskin untuk secara kolektif terlibat dalam pengambilan keputusan menanggulangi kemiskinan yang mereka alami sendiri. Perberdayaan merupakan aktvitas yang memperkuat keberdayaan kelompok lemah dalam masyarakat salah satunya individu-individu yang mengalamu masalah kemiskinan dengan tujuan mencapai keadaan atau hasil yang ingin dicapai leh sebuah perubahan atau sosial yaitu masyarakat yang berdaya. Pada akhirnya implementasi zakat yang dimulai dari penghimbunan dan penyaluran dana zakat mengurangi kemiskinan yang pada nantinya aan berdampak positi pada kehidupan sisial masyarakat (Nurwati \& Hendrawati, 2019).

\section{Kesimpulan}

Berdasarkan hasil yang diperoleh dalam peneletian terhadap faktor kemiskinan di Jawa tengah pada Tahun 2015-2019 mengunakan regresi data panel dapat disimpulkan sebagai berikut: Variabel produk domestik regional bruto tidak signifikan terhadap kemiskinan di Jawa Tengah. Indeks Pembangunan Manusia berpengaruh Negatif terhadap Kemiskinan di Jawa Tengah Zakat berpengaruh Negatif terhadap Kemiskinan di Jawa Tengah.

\section{Ucapan Terimakasih}

Peneliti mengucapakan banyak terimakasih kepada civitas ekademika Fakultas Ekonomi dan Bisnis Islam IAIN Salatiga yang telah mendukung terselesainya penelitian ini. Peneliti juga mengcupkan terimakasih kepada semua pihak yang membantu penyelesaian penelitian ini.

\section{Referensi}

Akbar, A. S. (2019). Analisis Pengaruh Zakat, Inflasi, Jumlah Penduduk Terhadap Tingkat Kemiskinan Indonesia Tahun 2013-2018. SKRIPSI, 53(9), 1689-1699.

Alhudhori, M. (2017). Pengaruh Ipm, Pdrb Dan Jumlah Pengangguran Terhadap Penduduk Miskin Di Provinsi Jambi. EKONOMIS: Journal of Economics and Business, 1(1), 113. https://doi.org/10.33087/ekonomis.v1i1.12

Aminah. (2018). Pengaruh Produk Domestik Regional Bruto (PDRB) dan Pengangguran terhadap Tingkat Kemiskinan pada Kab./kota Termiskin di Jawa Tengah Tahun 2013-2018. 
Asriyanti, F. (2020). Pengaruh Produk Domestik Regional Pendayagunaan Zakat Di Pulau Jawa.

Azizah, E. W., Sudarti, \& Kusuma, H. (2018). Pengaruh Pendidikan, Pendapatan Perkapita dan Jumlah Penduduk terhadap Kemiskinan di Provinsi Jawa Timur. Jurnal Ilmu Ekonomi, 2, 167-180.

Bintang, A. B. M., \& Woyanti, N. (2018). Pengaruh PDRB, Pendidikan, Kesehatan, Dan Pengangguran Terhadap Tingkat Kemiskinan Di Jawa Tengah (2011-2015). Media Ekonomi Dan Manajemen, 33(1), 20-28. https://doi.org/10.24856/mem.v33i1.563

Indahsari, F. (2019). Pengaruh Pengangguran Dan Pertumbuhan Ekonomi Dengan Distribusi Zakat sebagai Variabel Moderasi Terhadap Kemiskinan di Pulau Jawa Tahun 2012-2017.

Iskandar, Iskandar, Bawono, A., Rofiuddin, M., Pratiwi, D. N., \& Anwar, S. (2019). The Factors Analysis Of Affecting Labor On Interregional Migration. Proceedings of the 3rd International Conference on Indonesian Social \& Political Enquiries (ICISPE 2018). Atlantis Press.

Izza Rossalia. (2019). Analisis pengaruh indeks pembangunan manusia (ipm), pengangguran dan zakat terhadap kemiskinan di pulau jawa tahun 2012-2017. In Skripsi. Salatiga.

Lestari, R. P. (2017). Analisis Pengaruh Indeks Pembangunan Manusia, Pengangguran, Dan Produk Domestik Regional Bruto Terhadap Tingkat Kemiskinan Di Provinsi Lampung Dalam Perspektif Ekonomi Islam Tahun 20112015. Universitas Islam Negeri Raden Intan Lampung, 53(9), 1689-1699.

Lubis, D. S. (2017). Analisis Pengaruh Inflasi Dan Pertumbuhan Ekonomi Terhadap Pengangguran. At-Tijaroh: Jurnal IImu Manajemen Dan Bisnis Islam, 3(2), 180. https://doi.org/10.24952/tijaroh.v3i2.1356

Mohammad, R., \& Firmansyah. (2018). Income Inequality in Indonesia: Panel Data of 34 Provinces 2014-2016. E3S Web of Conferences, 73, 10003. https://doi.org/10.1051/e3sconf/20187310003

Murniati, R., \& Beik, I. S. (2012). Pengaruh Zakat Terhadap Indeks Pembangunan Manusia dan Tingkat Kemiskinan Mustahik: Studi Kasus Pendayagunaan BAZNAS Kota Bogor Influence of Zakat on Human Development Index and Poverty Level of Mustahik: Case Study of BAZNAS Utilization in Bogor. Jurnal Al-Muzara'ah, 2(2), 135-149.

Mustika, F. N. (2019). Analisis Pengaruh Zis (Zakat, Infaq , Dan Upah Minimum Regional Dan Inflasi Terhadap Tingkat Kemiskinan Di Indonesia.

Nurwati, N., \& Hendrawati, H. (2019). Zakat dan Upaya Mengentaskan Kemiskinan. Cakrawala: Jumal Studi Islam, 14(1), 40-47. https://doi.org/10.31603/cakrawala.v14i1.2695

Ridzky Giovanni. (2018). Analisis Pengaruh PDRB, Pengangguran dan Pendidikan Terhadap Tingkat Kemiskinan di Pulau Jawa Tahun 2009-2016. Economics Development Analysis Joumal, 7(1), 23-31. https://doi.org/10.15294/edaj.v7i1.21922

Rini, R., Fatimah, F., \& Purwanti, A. (2020). Zakat and poverty: An Indonesian 
experience. International Journal of Innovation, Creativity and Change, 10(11), 759-770.

Rofiuddin, M., Aisyah, S., Pratiwi, D. N., Annisa, A. A., Puspita, R. E., \& Nabila, R. (2019). Does Economic Growth Reduce Pollution? Empirical Evidence from Low Income Countries. E3S Web of Conferences, 125, 06002. https://doi.org/10.1051/e3sconf/201912506002

Rossalia, I. (2019). Analisis Pengaruh Indeks Pembangunan Manusia (Ipm), Pdrb, Dan Upah Minimum Terhadap Kemiskinan Studi Kasus Kabpaten/Kota Di Pulau Jawa. 1-100.

Saputra, W. A. (2011a). Analisis Pengaruh Jumlah Penduduk, PDRB, IPM, Pengangguran terhadap Tingkat Kemiskinan di Kabupaten / Kota Jawa Tengah. In Ekonomi dan Bisnis (Vol. 5). Semarang: Skripsi.

Saputra, W. A. (2011b). Tingkat Kemiskinan. Ekonomi Dan Bisnis, 5(27).

Sayifullah, S., \& Gandasari, T. R. (2016). Pengaruh Indeks Pembangunan Manusia Dan Pengangguran Terhadap Kemiskinan Di Provinsi Banten. Jurnal EkonomiQu, 6(2), 236-255. https://doi.org/10.35448/jequ.v6i2.4345

Sulistiano, V. edi. (2020). Pemerintah Terhadap Kemiskinan Di Indonesia Periode 2014-2019 Skripsi.

Tawakkal, M. I., \& Sapha, D. (2018). Pengaruh Zakat Terhadap Kemiskinan Di Provinsi Aceh. Jurnal IImiah Mahasiswa (JIM), 3(4), 704-711.

Widarjono. (2013). Ekonometrika Pengantar dan Aplikasinya: Disertai Panduan Eviews (UPP STIM Y). Yogyakarta.

Wijayanto, R. D. (2016). Analisis Pengaruh PDRB, Pendidikan Dan Pengangguran Terhadap Kemiskinan di Kabupaten / Kota Jawa Tengah Tahun 2005 - 2008. In Genome Announcements (Vol. 4). https://doi.org/10.1128/genomeA.00211-16 